ISSN 1412-2936

EISSN 2549-7308

\title{
PENGARUH PRICE DISCOUNT DAN BONUSPACK TERHADAP IMPULSE BUYING (STUDI KASUS PADA INDOMARET UNIT DIRGAHAYU)
}

\author{
Adriani Kusuma1), M. Noer Sudrajat ${ }^{2)}$, Ferdy Rachmad Kurniawan ${ }^{3)}$ \\ Fauzi@unira.ac.id
}

\author{
Universitas Madura
}

\begin{abstract}
Abstrak
Di tengah pergeseran pola usaha khususnya ritel dan semakin pesat pertumbuhannya. Maka diperlukan suatu strategi guna menarik para calon pembeli untuk hanya sekedar mampir dan sekaligus berbelanja item produk yang telah disediakan oleh rigtel tersebut. Hal ini diperlukan kiat guna memikat calon pembeli. Oleh karenanya penelitian ini mengangkat tema pengaruh price discount dan bonuspack terhadap impulse buying. Dengan menggunakan metode analisis regresi linier berganda. Dari hasil analisa regresi linear berganda menggunakan SPSS dapat diketahui $R=0,703$ yang berarti korelasi atau hubungan 2 variabel bebasnya bertaraf kuat.
\end{abstract}

\section{Keyword: price discount, bonuspack, dan impulse buying.}

\section{PENDAHULUAN}

\subsection{Latar Belakang}

Seiring dengan perkembangan

bisnis ritel tidak lagi dikelola secara tradisional, melainkan dengan cara modern. Hal ini ditandai dengan keberadaan pasar tradisional yang mulai tergeser oleh munculnya berbagai jenis pasar modern, sehingga berbagaimacam pusat perbelanjaan eceran bermunculan dengan berbagaima cambentukdan ukuran. Beberapa contoh bentuk pusat perbelanjaan modern seperti minimarket, supermarket, departmentstore, shopping center, mall dan hypermarket. Ritel adalah usaha menjual produk/dagangan kebutuhan rumah tangga, termasuk produk kebutuhan sehari-hari yang menggunakan system swalayan (konsumen mengambil barang/produk itu sendiri tanpa ada yang melayani.

Di indonesia terdapat beberapa merek diantaranya adalah Alfamart, Indomaret. Persaingan minimarket di Indonesia sangat ketat dan dapat dilihat dari banyaknya pesaing-pesaing minimarket yang sudah menjamur di indonesia. Hal tersebut ditangkap oleh
PT.Indomarco Primatama yang mewujudkannya dengan mendirikan Indomaret yang memiliki visi "menjadi jaringan ritel yang unggul" dengan moto "mudahdanhemat". Seiring berjalannya waktu, saat ini manajemen Indomaret telah menguasai pengetahuan dan pengoperasian jaringan ritel dalam skala besar.

Price discount dan bonuspack merupakan promosi penjualan yang paling banyak digunakan, baik penjualan online maupun offline (Kotler \& Keller, 2009;134). Price discount adalah strategi promosi penjualan berbasis harga dimana pelanggan ditawarkan produk yang sama dengan harga yang berkurang, sedangkan bonus pack merupakan strategi promosi penjualan berbasis kuantitas dimana pelanggan ditawarkan produk dengan kuantitas yang lebih dengan harga yang sama (Kotler \&Amstrong 2008;156). Xu, Y., dan Huang,J.S, dalam penelitiannya yang berjudul "Effectsof Price Discountsand Bonus Packson Online Impulse Buying", menyatakan bahwa variabel price discount akan lebih memicu impulse buying konsumen dibandingkan variabel 
bonuspac kapabila produk yang ditawarkan memiliki harga yang murah, sedangkan variabel bonus pack akan lebih memicu impulse buying konsumen dibandingkan variabel price discount ketika barang yang ditawarkan memiliki harga yang mahal.

Sebagai bisnis ritel yang terkemuka dan mempunyai reputasi nasional maka Indomaret telah mendapatkan kepercayaan dari masyarakat. Namun demikian masih sering muncul juga keluhan dari pelanggan terhadap layanan minimarket Indomaret dibeberapa media cetak maupun media online. Untuk itu beberapa kasus terkait price discount dan bonus pack yang pernah terjadi di beberapa minimarket Indomaret akan menjadi rujukan.

Berdasarkan latar belakang yang dikemukakan sebelumnya maka penulis tertarik untuk melakukan penelitian mengenai "Pengaruh Price Discoun tdan Bonus Pack terhadap Impulse Buying" (Studi pada Indomaret JI. Dirgahayu, Pamekasan), sehingga melalui penelitian ini diharapkan dapat dijadikan dasar bagi pihak perusahaan melalui perbaikan- perbaikan atas pelayanan dan produk yang ditawarkan.

\subsection{Rumusaan Masalah}

Berdasarkan batasan masalah yang dikemukakan di atas, maka perumusan masalah dalam penelitian iniyaitu:
1. Apakah price discount dan bonus pack berpengaruh terhadap impulse buying dilndomaret Pamekasan?

2. Variabel maanakah antara price discount dan bonus pack yang berpengaruh paling dominan terhadap impulse buying dilndomaret Pamekasan?

\subsection{Batasan Masalah}

Untuk menghindari pembahsan yang meluas makapenulis membatasi penelitian ini pada:

1. Price discount dan Bonus pack terhadap Impulse buying untuk kategori produk convenience goods atau barang kebutuhan sehari-hari dilndomaret di JI. Dirgahayu Pamekasan.

2. Responden Penelitian ini adalah Pelanggan Indomaret di Jl. Dirgahayu Pamekasan.

\subsection{Tujuan Masalah}

Berdasarkan rumusan masalah diatas,maka tujuan penelitian ini untuk mengetahui:

1. Untuk mengetahui apakah price discount dan bonus pack terhadap impulse buying dilndomaret Pamekasan.

2. Untuk mengetahui variabel maanakah antara price discount dan bonus pack yang berpengaruh paling dominan terhadap impulse buying di Indomaret Pamekasan? 


\subsection{Kerangka Pemikiran}

Gambar 1.1

Kerangka Pemikiran

Pengaruh Price Discountdan Bonus Pack terhadap Impulse Buying

(Studi pada Indomaret Unit Dirgahayu Pamekasan)

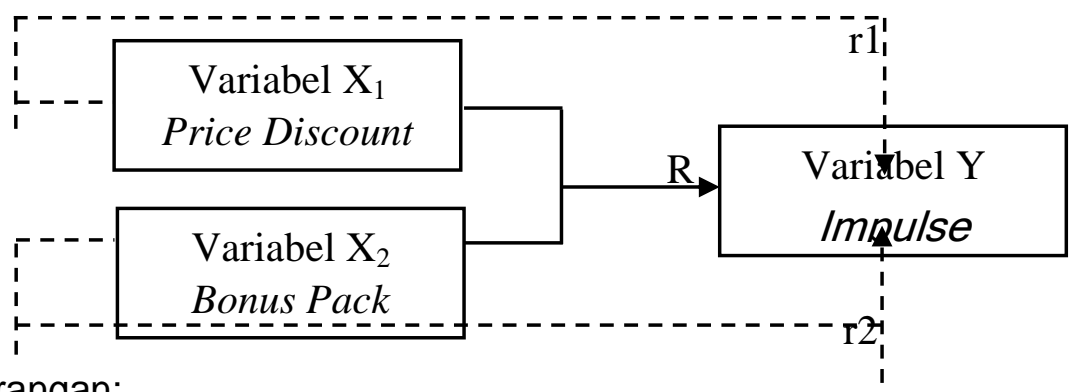

Keterangan:

r1 : : Untuk mengetahui pengaruh Price Discount terhadap Impulse Buying

r2 : Untuk mengetahui pengaruh Bonus Pack terhadap Impulse Buying

R : Untuk mengetahui pengaruh Price Discount\&Bonus Pack terhadap Impulse Buying

$\mathrm{X}_{1} \quad$ : Price Disciunt

$\mathrm{X}_{2}$ : Bonus Pack

Y : : Impulse Buying

\section{KAJIAN PUSTAKA DAN HIPOTESIS}

\subsection{Penelitian Sebelumnya}

Beberapa peniliti telah melakukan studi tentang Impulse Buying. Hasil penelitian dapat dijelaskan sebagai berikut:

1. Putri,Y.T.A. dan Edwar,M., (2014)

Dalam penelitiannya yang berjudul "Pengaruh Bonus Pack dan Price Discount terhadap Impulse Buying pada Konsumen Giant Hyper market Diponegoro Surabaya", menyatakan bahwa" terdapat pengaruh bonus pack dan price discount terhadap impulse buying pada konsumen Giant Hypermarket Diponegoro Surabaya" terbukti akan kebenarannya atau dengan kata lain variabel bonus pack dan price discount secara simultan atau bersama-sama mempengaruhi variabel impulse buying.

2. Xu,Y.,dan Huang, J.S. (2014)

Dalam penelitiannya yang berjudul "Effectsof Price Discounts and Bonus
Packs on Online Impulse Buying". Menyatakan bahwa variabel price discount akan lebih memicu niat membeli konsumendi bandingkan variabel bonus pack apabila produk yang ditawarkan memiliki harga yang murah, sedangkan variabel bonus pack akan lebih memicu niat membeli konsumn dibandingkan variabel price discount ketika barang yang ditawarkan memiliki harga yang mahal.

\subsection{Landasan Teori}

a. Tinjauan Tentang Impulse Buying

Menurut Mowen \& Minor (2010) definisi pembelian impulsif (impulse buying) adalah tindakan membeli yang dilakukan tanpa memiliki masalah sebelumnya atau $\mathrm{maksud} /$ niat membeli yang terbentuk sebelum memasuki toko. Sedangkan 
menurut Harper $(2000 ; 112)$ Impulse Buying merupakan keputusan yang emosional atau menurut desakan hati. Hal senada diungkapkan juga oleh Isnaini $(2005 ; 126)$ mengatakan bahwa impulse buying berkaitan dengan perilaku untuk membeli berdasarkan emosi. Emosi ini berkaitan dengan pemecahan masalah pembelian yang terbatas atau spontan. Kotler \& Keller $(2009 ; 156)$ menjelaskan bahwa impulse buying terjadi ketika konsumen mengambil keputusan pembelian yang mendadak. Dorongan untuk melakukan pembelian begitu kuat, sehingga konsumen tidak lagi berpikir rasional dalam pembeliannya.

Pembelian merupakan fungsi dari niat, pengaruh lingkungan dan perbedaan individu. Umumnya pembelian direncanakan sepenuhnya dalam pengertian ada niat untuk membeli produk ataupun merek tertentu. Tetapi pada kenyataannya konsumen sering tidak menggunakan pikiran rasionalnya dalam menentukan barang-barang yang benar-benar dibutuhkan sehingga pembelian terjadi tanpa direncanakan secara khusus. Pembelian inilah yang dikenal dengan istilah pembelian impulse buying (Wathani, 2009:132).

Engel dan Blackwell dalam Semuel (2006:105) mendefinisikan pembelian yang tidak direncanakan atau unplanned buying adalah suatu tindakan pembelian yang dibuat tanpa direncanakan sebelumnya atau keputusan pembelian dilakukan pada saat berada di dalam toko. Secara umum, konsumen telah merencanakan apa yang hendak dibeli. Menurut Utami (2010:67), pembelian impulsif terjadi ketika konsumen tiba-tiba mengalami keinginan yang kuat dan kukuh untuk membeli secepatnya.

Dari beberapa pengertian diatas, maka dapat disimpulkan bahwa impulse buying adalah perilaku membeli konsumen dimana konsumen tersebut melakukan pembelian tanpa adanya perencanaan,terjadi dengan tibatiba, dan keinginan yang kuat untuk membeli sesuatu dengan segera tanpa adanya suatu pertimbangan untuk akibat yang akan dihadapi. Sehingga konsumen tidak lagi berpikir rasional dalam perilaku pembelian.

Menurut Srern dalam Utami (2010:68) ada empat tipe pembelian impulsif, yaitu: pure impulse, reminder impulse, suggestion impulse, dan planned impulse.

a. Pure Impulse

Pengertian ini mengacu pada tindakan pembelian karena alasan menarik, biasanya ketika pembelian terjadi karena loyalitas merek atau perilaku pembelian yang telah biasa dilakukan.

b. Reminded Impuls

Ketika konsumen membeli berdasarkan jenis impuls ini, hal ini dikarenakan unit tersebut biasanya memang dibeli juga, tetapi tidak terjadi untuk diantisipasi atau tercatat dalam daftar belanja.

\section{c. Suggestion impulse}

Suatu produk yang ditemui konsumen untuk pertama kali akan menstimuli keinginan untuk mencobanya.

d. Planned impulse

Aspek perencanaan dalam perilaku ini menunjukkan respons konsumen terhadap beberapa stimulus untuk membeli unit yang tidak diantisipasi, ini biasanya distimulasi oleh pengumuman penjualan kupon, potongan kupon, atau penawaran menggiurkan lainnya.

Menurut Utami (2010:69) kondisi-kondisi yang memudahkan terjadinya pembelian impulsif di supermarket adalah sebagai berikut:

a. Besarnya transaksi, semakin banyaknya macam produk yang 
dibeli, presentase terjadinya pembelian impulsif akan semakin meningkat pula.

b. Perjalanan belanja, presentase terjadinya pembelian impulsif semakin tinggi terjadi sewaktu konsumen melakukan perjalanan belanja daripada perjalanan biasa.

c. Frekuensi belanja, pembelian impulsif semakin besar kemungkinannya terjadi apabila sering melakukan pembelian daripada yang jarang melakukan pembelian.

d. Daftar belanja, daftar yang telah ditentukan terlebih dahulu dapat menyebabkan kemungkinan besar terjadinya pembelian impulsif, tetapi hanya bila jumlah unit belanjanya besar, umumnya lebih dari 15 item.

\section{b. jauan Tentang Price Discount}

Menurut Kotler \& Keller $(2009 ; 127) \quad$ price discount merupakan penghematan yang ditawarkan pada konsumen dari harga normal akan suatu produk, yang tertera di label atau kemasan produk tersebut. Harper $(2000 ; 123)$ mengatakan bahwa price discount memberikan beberapa keuntungan diantaranya: dapat memicu konsumen untuk membeli dalam jumlah yang banyak, mengantisipasi promosi pesaing, dan mendukung perdagangan dalam jumlah yang lebih besar.

Menurut Kotler dan Armstrong $(2008 ; 198)$ price discount merupakan potongan harga yang diberikan oleh penjual kepada pembeli sebagai penghargaan atas aktivitas tertentu dari pembeli yang menyenangkan bagi penjual. Para konsumen tertarik untuk mendapatkan harga yang pantas. Harga yang pantas berarti nilai yang dipersepsikan pantas padasaat transaksi dilakukan.

Dalam pemasaran, Price Discount (Potongan harga) merupakan alat promosi yang dapat menarik perhatian konsumen untuk mendorong hasrat calon konsumen guna membeli produk yang ditawarkan. Menurut Sutisna (2002:302) Potongan harga adalah pengurangan harga produk dari harga normal dalam periode tertentu. Sedangkan menurut Peter dan Olson (2014:256) Potongan harga adalah strategi menentukan harga yang melibatkan rencana jangka panjang untuk menurunkan harga secara sistematis setelah mengenalkan produk dengan harga tinggi. Menurut Tjiptono (2008:166)

Dari pengertian di atas dapat di atas dapat disimpulkan bahwa price discount merupakan potongan harga yang diberikan oleh penjual kepada konsumen.

Menurut Kotler dan Armstrong $(2008 ; 201)$ ada beberapa macam bentuk dari price discount, yaitu:

1) Diskon Tunai

Diskon tunai adalah pengurangan harga untuk pembeli yang segera membayar tagihannya atau membayar tagihan tepat pada waktunya

2) Diskon Kuantitas (Quantity Discount)

Merupakan pengurangan harga bagi pembeli yang membeli dalam jumlah besar.

3) Diskon Fungsional ( Functional Discount)

Diskon fungsional juga disebut diskon perdagangan (Trade Discount),

4) Diskon Musiman (Seasonal Discount)

Diskon musiman merupakan pengurangan harga untuk pembeli yang membeli barang atau jasa di luar musimnya.

5) Potongan (Allowance)

Potongan tukar tambah adalah pengurangan harga yang diberikan untuk menyerahkan barang lama ketika membeli yang baru

Sedangkan menurut Ma'ruf $(2006 ; 178)$ ada beberapa alasan 
perusahaan memprakarsai price discount, yaitu:

1) Kelebihan kapasitas.

2) Merosotnya bagian pasarakibat makin ketatnya persaingan.

3) Untuk mengunggulkan pasar melalui biaya yang lebih rendah

Pada prakteknya di Indonesia, potongan harga umumnya diberikan pada item-item produk yang sudah out of date, atau item produk yang tidak laku. Pada retailer-retailer, pemberian potongan harga ini bukan berasal dari retailer, tetapi berasal dari penjual merek yang dijual di retailer tertentu.

Menurut Sutisna (2002:303) tujuan pemberian potongan harga adalah:
a. Mendorong pembelian dalam jumlah besar.
b. Mendorong agar pembelian dapat dilakukan dengan kontan atau waktu yang lebih pendek.
c. Mengikat pelanggan agar tidak berpindah ke perusahaan lain.

\section{c. Tinjauan Tentang Bonus Pack}

Menurut Mowen \& Minor (2002;203) bonus pack menawarkan konsumen sebuah muatan ekstra dari sebuah produk dengan harga normal. Menurut Ma'ruf $(2006 ; 218)$ bonus pack merupakan strategi promosi penjualan berbasis kuantitas di mana pelanggan di tawarkan produk dengan kuantitas lebih dengan harga yang sama. Kotler dan Armstrong (2008;221) mendefinisikan bonus pack adalah tambahan produk dari perusahaan untuk diberikan kepada konsumen dengan harga yang sama

Dari beberapa pengertian diatas, dapat disimpulkan bahwa bonus pack adalah merupakan salah satu strategi dalam promosi penjualan yang menawarkan produk atau jasa dengan gratis dengan harga yang sudah dikurangi untuk mendorong pembelian produk lain.

Kotler \& Keller (2009;189) menyebutkan manfaat dari penggunaan strategi bonus pack ini,yaitu:
1) Memberikan pemasar cara langsung untuk menyediakan nilai ekstra.

2) Merupakan strategi bertahan yang efektif terhadap kemunculan promosi produk baru dari pesaing.

3) Menghasilkan pesanan penjualan yang lebih besar.

Menurut Isnaini $(2005 ; 185)$ bonus pack dapat memiliki kekurangan bila ditinjau dari kemampuan pergudangan, pengiriman, inventaris dan penyusunan produksi. Kekurangan bonus dalam kemasan ini dapat mengakibatkan perusahaan akan menghentikan promosi tersebut.

Sejak suatu jumlah yang ditambahkan diberikan secara gratis, konsumen mungkin akan terbujuk untuk membeli produk tersebut jika mereka merasa mendapatkan penawaran yang adil daripada nilai dari uang mereka. Promosi ini biasa digunakan untuk meningkatkan pembelian impulsif (impulse buying) oleh konsumen. Sejak isi produk ditambahkan dan tidak ada biaya extra, konsumen dapat dibujuk untuk membeli produk tersebut. Jika mereka merasa mendapatkan nilai yang lebih besar daripada uang yang mereka belanjakan. Belch dan Belch dalam Amanda (2014:535), menyebutkan manfaat dari penggunaan strategi bonus pack ini, yaitu:

a. Memberikan pemasar cara langsung untuk menyediakan nilai ekstra.

b. Merupakan strategi bertahan yang efektif terhadap kemunculan promosi produk baru dari pesaing.

c. Menghasilkan pesanan

\subsection{Hipotesis} penjualan yang lebih besar.

Berdasarkan pada landasan teori dan kerangka berfikir yang telah dikemukakan sebelumnya,maka hipotesis dalam penelitian ini adalah sebagai berikut:

$\mathrm{H}-\mathrm{I} \quad$ : Price discount dan bonus pack berpengaruh terhadap impulse buying pada pelanggan Indomaret Pamekasan? 
$\mathrm{H}-\mathrm{II}$ : Variabel price discount yang berpengaruh paling dominan terhadap impulse buying pada pelangganlndomaret

Pamekasan?

METODE PENELITIAN

\subsection{Lokasi Penelitian}

Lokasipenelitian dilakukan dilndomaret yang beralamat di Jl. Dirgahayu Pamekasan.

\subsection{Jenis Penelitian}

Jenis penelitian yang digunakan dalam penelitian ini adalah jenis penelitian asosiatif. Penelitian asosiatif merupakan penelitian yang mencari hubungan antara satu atau beberapa variabel dengan variabel lain (Sugiyono, 2002;7). Dengan demikian penelitian ini dapat berfungsi untuk menjelaskan, serta meramalkan tentang pengaruh Price Discount dan Bonus Pack terhadap Impulse Buyingdi Indomart Pamekasan.

\subsection{Jenis Dan Sumber Data}

\section{a. Jenis Data}

Dalam penelitian ini data yang digunakan adalah data kuantitatif yaitu data yang berbentuk angka, atau data kualitatif yang diangkakan.

\section{b. Sumber Data}

Data menurut sumbernya ada dua yaitu data primer dan data sekunder. Data primer biasanya diperoleh langsung dari sumbernya yang biasanya menggunakan angket atau wawancara, sedangkan data sekunder adalah data sumbernya tidak langsung dari objeknya seperti data statistic.

Dari penjelasan diatas menurut sumbernya pada penelitian ini termasuk data primer karena menggunakan angket, sedangkan data sekunder adalah data pelengkap.

\subsection{Populasi Dan Sampel}

\section{a. Populasi}

Populasi adalah wilayah generalisasi yang terdiridari objek atau subjek penelitian yang mempunyai kuantitas dan karakteris tiktertentu yang diterapkan oleh peneliti untuk dipelajari dan kemudian ditarik kesimpulannya (Sugiyono,2004;55). Populasi dalam penelitian ini adalah pengunjung yang melakukan pembelian di Indomaret Jl. Dirgahayu Pamekasan.

\section{b. Sampel}

Melihat jumlah populasi yang diteliti sangatlah besar, maka tidak mungkin semua individu/objek pada populasi tersebut diteliti satu persatu, untuk itu perlu melakukan pengambilam sampel dari populasi tersebeut. Sampel adalah bagian dari jumlah dan karakteristik yang dimiliki oleh populasi tersebut(Sugiyono, 2005;56).

Teknik pengambilan sampel dalam penelitian ini adalah dengan menggunakan tehnik Disproportional Strafied Random Sample (Penarikan sampel tidak beraturan), Menurut Ferdiand $(2006 ; 59)$ untuk penarikan jumlah sampel disarankan "Jumlah sampel yang sesuai berkisar antara 100200 responden". Berdasarkan pendapat itulah peneliti menarik jumlah sampel sebanyak 170 orang.

\subsection{Definisi Operasional}

\section{a. Variabel Independent (Bebas)}

Variabel bebas merupakan variabel yang mempengaruhi atau yang menjadi penyebab bagi variabel lain. Dalam penelitian ini yang menjadi variabel bebas adalah:

\section{1) Variabel Price Discount $\left(X_{1}\right)$}

Indikator yang digunakan untuk mengukur variabel price discount terdiri dari 3 indikator yaitu: dapat memicu konsumen untuk membeli dalam jumlah yang banyak, mengantisipasi promosi pesaing, dan mendukung perdagangan dalam jumlah yang lebih besar.

2) Variabel Bonus Pack $\left(X_{2}\right)$

Variabel bonus pack dalam penelitian ini diukur melalui 3 
indikator yang meliputi: memberikan penawaran dengan manfaat ekstra, strategi bertahan terhadap promosi produk baru dari pesaing dan menghasilkan pesanan penjualan yang lebih besar.

\section{b. Variabel Dependent (Terikat)}

Variabel dependen adalah variabel yang menjadi pusat perhatian peneliti (Ferdinand,2006;122). Variabel dependen merupakan variabel yang nilainya tergantung dari variabel lain, dimana nilainya akan berubah jika variabel yang mempengaruhinya berubah. Dalam penelitian ini yang menjadi variabel bebas adalah Impulse Buying.

Indikator yang digunakan untuk mengukur variabel impulse buying terdiri dari 4 indikator yaitu spontanitas pembelian, tidak mempertimbangkan konsekuensi, keinginan membeli tiba-tiba di ikuti dengan emosi dan tidak dapat menolak keinginan.

\subsection{Tekhnik Pengumpulan Data}

Untuk memperoleh data yang aktual dalam penelitian ini, maka teknik pengumpulan data yang digunakan peneliti yakni melalui penyebaran angket, yaitu menyebarkan daftar pertanyaan yang telah disusun kepada responden berdasarkan indikator yang telah ditetapkan.

Dalam penelitian ini indikatorindikator diukur dengan menggunakan skala Likert yang mempunyai lima tingkat preferensi yang masing-masing memiliki skor antara1 sampai 5 dengan ketentuan sebagai berikut:

Sangat tidak setuju skor 1

Tidak setuju skor 2

Cukup setuju skor 3

Setuju skor 4

Sangat setuju skor 5

\subsection{Pengujian Instrumen Data}

\section{a. Uji Validitas}

Uji validitas dilakukan untuk mengetahui apakah alat ukur yang telah disusun benar - benar mampu mengukur apa yang harus diukur. Uji validitas digunakan untuk menguji seberapa cermat suatu alat ukur dalam melakukan fungsi ukurannya. Pengujian validitas tiap butir digunakan analisis item, yaitu mengkorelasikan skor tiap butir dengan skor total yang merupakan jumlah tiap skor butir (corrected item total correlation) yang penyelesaiannya dilakukan. Uji validitas dilakukan dengan membandingkan antara $r_{\text {hitung }}$ dengan $r_{\text {tabel }}$

Sedangkan Kriteria pengujiannya dikatakan valid jika $r_{\text {hitung }}>r_{\text {tabel }}$ dan tidak valid jika $r_{\text {hitung }}<r_{\text {tabel. }}$. Butir - butir instrumen dianggap valid apabila koefisien korelasi $\left(r_{\text {hitung }}\right)$ lebih besar dari $r_{\text {kritis }} \quad(0,30) \quad$ (Sugiyono, 157;2004). Dengan penilaian :

1) Nilai $r=+1$ atau mendekati 1 , maka korelasi antara $X$ dan $Y$ dikatakan positif dan sangat kuat sekali.

2) Nilai $r=-1$ atau mendekati -1 , maka korelasi antara $X$ dan $Y$ dikatakan sangat kuat dan negatif.

3) Nilai $r=0$ atau mendekati nol, maka hubungan antara kedua variabel sangat lemah atau tidak ada hubungan sama sekali.

\section{b. Uji Reliabilitas}

Uji reliabilitas bertujuan untuk mengetahui apakah alat pengumpul data pada dasarnya menunjukkan tingkat ketepatan, keakuratan kestabilan atau konsistensi alat tersebut dalam mengungkapkan gejala - gejala tertentu dari sekelompok individu, walaupun dilakukan pada waktu yang berbeda. Uji reliabilitas dilakukan terhadap pertanyaan yang telah valid. Rumus yang dipakai adalah untuk menguji reabilitas dalam penelitian adalah Cronbach Alpha yang penyelesaiannya dilakukan dengan membandingkan antara $r_{\text {alpha }}$ dan $r_{\text {tabel. }}$.

$$
\text { Menurut Singgih }(2002 ; 227)
$$

Secara umum keandalan dalam kisaran

$$
\begin{array}{ll}
0,00 \mathrm{~s} / \mathrm{d} 0,20 & \text { Kurang baik } \\
>0,20 \mathrm{~s} / \mathrm{d} 0,40 & \text { Agak baik } \\
>0,40 \mathrm{~s} / \mathrm{d} 0,60 & \text { Cukup baik } \\
>0,60 \mathrm{~s} / \mathrm{d} 0,80 & \text { Sangat Baik }
\end{array}
$$


$>0,80 \mathrm{~s} / \mathrm{d} 1,00 \quad$ Sangat baik

Rumus Cronbach's Alpha adalah sebagai berikut.

$$
r_{11}=\left(\frac{k}{(k-1)}\right)\left(1-\frac{\sum \sigma_{b}^{2}}{\sigma_{t}^{2}}\right)
$$

Keterangan:

$r_{11} \quad$ : ReliabilitasInstrumen

$\sum \sigma_{b}^{2}:$ Jumlah Varians Butir

$\sigma_{t} \quad$ : Varians Total

k : Banyaknya butir pertanyaan atau banyaknya soal Setelah memperoleh angka reliabilitas, langkah selanjutnya adalah mengkonsultasikan harga tersebut dengan tabel rProduct Moment (taraf signifikan 5\%). Jika $r_{\text {hitung }}>r_{\text {tabel, }}$, maka instrument tersebut reliable.

\subsection{Tekhnik Analisis Dan Uji Hipotesis}

\section{a. Teknik Analisis Data}

Penelitian ini menggunakan teknik analisis statistik, yaitu dengan menggunakan Analisa Regresi Linear Berganda. Model analisis merupakan analisis yang bersifat kuantitatif, yang digunakan untuk mengetahui sejauh mana pengaruh Price Discount dan Bonus Pack Tehadap Impulse Buying pada Indomaret Pamekasan dengan menggunakan rumus :

Keterangan :

$$
Y=a+b_{1} X_{1}+b_{2} X_{2}
$$

$\mathrm{Y}=$ variabel terikat (Impulse

Buying)

$\mathrm{a}=$ bilangan konstanta

$b_{1}=$ koefisien regresi $X_{1}$

$b_{2}=$ koefisien regresi $X_{2}$

$\mathrm{X}_{1}=$ variabel bebas (Price

Discount)

$\mathrm{X}_{2}=$ variabel bebas (Bonus

Pack)

b. Uji Hipotesis

1) Uji $F$

Pengujian hipotesis kedua dilakukan dengan memanfaatkan uji statistik $F$ (uji serentak), dengan rumus sebagai berikut :

$$
F=\frac{R^{2} / k}{\left(1-R^{2}\right) /(n-k-1)}
$$

Keterangan :

$$
\begin{aligned}
& \mathrm{F}=\text { rasio } \\
& \mathrm{R}^{2}=\text { hasil perhitungan } \mathrm{R} \\
& \text { dipangkatkan dua } \\
& \mathrm{k}=\text { jumlah variabel bebas } \\
& \mathrm{n}=\text { banyaknya sampel }
\end{aligned}
$$

Berdasarkan hipotesis yang telah diajukan sebelumnya, maka untuk pengujian hipotesis (3), diuji sebagai berikut :

$\mathrm{H} 1 \quad \mathrm{~b} 1=\mathrm{b} 2=0$, artinya secara bersama - sama tidak ada pengaruh yang signifikan antara variabel 2) Uji t

$\mathrm{X}_{1}$ dan $\mathrm{X}_{2}$ terhadap variabel $\mathrm{Y}$.

Digunakan untuk mengetahui pengaruh dari masing - masing variabel, baik variabel bebas terhadap variabel terikat tersebut yang signifikan secara statistik. Menggunakan uji masingmasing koefisien regresi variabel bebas apakah mempunyai pengaruh yang bermakna atau tidak terhadap variabel terikat. (Sugiono, 2005;223)

$$
\begin{aligned}
& t=r \frac{\sqrt{n-2}}{\sqrt{1-r^{2}}} \\
& \text { Keterangan : } \mathrm{r}= \text { koefisien } \\
& \text { responden } \mathrm{n}=\text { jumlah }
\end{aligned}
$$

Adapun langkah-langkah analisis uji parsial adalahsebagai berikut : Apabila $\mathrm{t}_{\text {hitung }} \leq \mathrm{t}_{\text {tabel }}$ maka Ho diterima dan $\mathrm{H} 1$ ditolak, yang berarti tidak ada pengaruh yang bermakna oleh variabel $X$ dan $Y$. Jika $t_{\text {hitung }} \geq t_{\text {tabel }}$ maka Ho ditolak dan $\mathrm{H} 1$ diterima, yang berarti ada pengaruh yang bermakna oleh variabel $X$ dan $Y$.

\section{BAB IV}

\section{HASIL PENELITIAN DAN PEMBAHASAN}

\subsection{Hasil Penelitian}

a. Tinjauan Tentang Indomaret

Kebanyakan orang Indonesia sudah tahu dengan perusahaan yang 
bergerak dibidang ritel ini, jadi untuk sub-bab ini saya akan sedikit menceritakan tentang Indomaret. Indomaret yang letaknya di Jl. Dirgahayu Pamekasan memiliki 6 pegawai tiap Unit yang terbagi dalam dua sift (Siang dan Malam).

\section{Uji Validitas Dan Reabilitas Angket}

Ada dua syarat penting yang berlaku pada sebuah angket yaitu valid dan reliabel. Status Angket dikatakan valid jika item-item pada angket mampu untuk mengungkapkan yang akan diukur oleh angket tersebut. Sedangkan angket tersebut reliable apabila jawaban respon den terhadap variabel - variable tersebut konsisten dari waktu kewaktu.

Item-item tersebut jika mempunyai nilai $r_{\text {hitung }}>r_{\text {table }}$ yaitu apabila validitas tersebut mencapai $>0.30$ (Sugiono,2001:233) maka item-item tersebut dikatakan valid. Sedangkan apabila mempunyai variabel-variabel tersebut mempunyai cronbach'alpa diatas $60 \%(0.60)$ maka variable tersebut di katakana reliabel. Dalam penelitian ini kevalidan dan kerealibelan item dapat diuraikan sebagai berikut:

Tabel 4.1

UjiValiditasdanReabilitas

\begin{tabular}{|c|c|c|c|c|}
\hline Variabel & No Item & Nilai & Probabilitas & Ket \\
\hline \multirow{4}{*}{$\begin{array}{l}\text { Price Discount } \\
\qquad\left(\mathrm{X}_{1}\right)\end{array}$} & $X_{1.1}$ & 0,644 & 0,000 & Valid \\
\hline & $X_{1} .2$ & 0,514 & 0,000 & Valid \\
\hline & $X_{1} .3$ & 0,879 & 0,000 & Valid \\
\hline & Cronchbanch Alpha & 0,689 & & Reliabel \\
\hline \multirow[t]{4}{*}{ Bonus Pack $\left(\mathrm{X}_{2}\right)$} & $\mathrm{X}_{2.1}$ & 0,569 & 0,000 & Valid \\
\hline & $X_{2} .2$ & 0,568 & 0,000 & Valid \\
\hline & $X_{2.3}$ & 0,582 & 0,000 & Valid \\
\hline & Cronchbanch Alpha & 0,660 & & Reliabel \\
\hline \multirow{5}{*}{$\begin{array}{l}\text { Impulse Buying } \\
\text { (Y) }\end{array}$} & $\mathrm{Y} 1$ & 0,381 & 0,000 & Valid \\
\hline & Y2 & 0,554 & 0,000 & Valid \\
\hline & Y3 & 0,395 & 0,000 & Valid \\
\hline & Y4 & 0,644 & 0,000 & Valid \\
\hline & Cronchbanch Alpha & 0,618 & & Reliabel \\
\hline
\end{tabular}

Dari tabel 4.1diatas dapat disimpulkan bahwa setiap item angket yang diberikan kepada responden sudah valid dan reliabel. Hal ini terbukti nilai $r_{\text {hitung }}>r_{\text {tabel }}$ mencapai diatas 0.30 dan cronbach's alpha diatas $60 \%$ (0.60).

\section{b. Gambaran Deskripsi Item}

Gambaran diskripsi ini akan menyajikan gambaran mengenai item atas hasil jawaban angket yang telah disebarkan kepada pelanggan Jakarta ponsel Pamekasan sebagai berikut: 
ISSN 1412-2936

EISSN 2549-7308

Tabel 4.2

Frequensi Variabel $\mathrm{X}_{1}$

\begin{tabular}{|c|c|c|c|c|}
\hline Variabel & Soal & Skor & Frequensi & Persentase \\
\hline \multirow{18}{*}{$\mathrm{X} 1$} & \multirow[t]{5}{*}{1} & 1 & 0 & 0,0 \\
\hline & & 2 & 0 & 0,0 \\
\hline & & 3 & 55 & 32,4 \\
\hline & & 4 & 68 & 40,0 \\
\hline & & 5 & 47 & 27,6 \\
\hline & \multicolumn{2}{|c|}{ Total } & 170 & 100 \\
\hline & \multirow[t]{5}{*}{2} & 1 & 0 & 0,0 \\
\hline & & 2 & 0 & 0,0 \\
\hline & & 3 & 33 & 19,4 \\
\hline & & 4 & 89 & 52,4 \\
\hline & & 5 & 48 & 28,2 \\
\hline & \multicolumn{2}{|c|}{ Total } & 170 & 100 \\
\hline & \multirow[t]{5}{*}{3} & 1 & 0 & 0,0 \\
\hline & & 2 & 21 & 12,4 \\
\hline & & 3 & 75 & 44,1 \\
\hline & & 4 & 20 & 11,8 \\
\hline & & 5 & 54 & 31,8 \\
\hline & \multicolumn{2}{|c|}{ Total } & 170 & 100 \\
\hline
\end{tabular}

Dari tabel 4.2 dapat diketahui bahwa responden yang menyatakan sangat tidak setuju tidak ada, yang menyatakan tidak setuju juga tidak ada, yang menyatakan cukup setuju berjumlah 55 responden $(32,4 \%)$, yang menyatakan setuju berjumlah 68 responden (40\%) dan responden yang menyatakan sangat setujuberjumlah 47 responden $(27,6 \%)$ dan seterusnya untuk soal no.2 dan no.3.

Tabel 4.3

Frequensi Variabel $\mathrm{X}_{2}$

\begin{tabular}{|c|c|c|c|c|}
\hline Variabel & Soal & Skor & Frequensi & Persentase \\
\hline \multirow{10}{*}{$\mathrm{X} 2$} & \multirow[t]{5}{*}{1} & 1 & 0 & 0,0 \\
\hline & & 2 & 14 & 8,2 \\
\hline & & 3 & 34 & 20,0 \\
\hline & & 4 & 75 & 44,1 \\
\hline & & 5 & 47 & 27,6 \\
\hline & \multicolumn{2}{|c|}{ Total } & 170 & 100 \\
\hline & \multirow[t]{4}{*}{2} & 1 & 0 & 0,0 \\
\hline & & 2 & 20 & 11,8 \\
\hline & & 3 & 54 & 31,8 \\
\hline & & 4 & 62 & 36,5 \\
\hline
\end{tabular}


ISSN 1412-2936

EISSN 2549-7308

\begin{tabular}{|c|c|c|c|}
\hline \multicolumn{2}{|c|}{5} & 34 & 20,0 \\
\hline \multicolumn{2}{|c|}{ Total } & $\mathbf{1 7 0}$ & $\mathbf{1 0 0}$ \\
\hline \multirow{3}{*}{3} & 1 & 0 & 0,0 \\
\cline { 2 - 5 } 20 \\
\cline { 2 - 5 } & 2 & 7 & 4,1 \\
\cline { 2 - 5 } & 3 & 35 & 20,6 \\
\cline { 2 - 5 } & 4 & 80 & 47,1 \\
\cline { 2 - 5 } & 4 & 48 & 28,2 \\
\hline \multicolumn{2}{|c|}{ Total } & $\mathbf{1 7 0}$ & $\mathbf{1 0 0}$ \\
\hline
\end{tabular}

Dari tabel 4.3 dapat diketahui bahwa responden yang menyatakan sangat tidak setuju tidak ada, yang menyatakan tidak setuju sebanyak 14 responnden $(8,2 \%)$, yang menyatakan cukup setuju berjumlah 34 responden
(20\%), yang menyatakan setuju berjumlah 75 responden $(44,1 \%)$ dan responden yang menyatakan sangat setujuberjumlah 47 responden $(27,6 \%)$ dan seterusnya untuk soal no.2 dan no.3

Tabel 4.4

Frequensi Variabel $Y$

\begin{tabular}{|c|c|c|c|c|}
\hline Variabel & Soal & Skor & Frequensi & Persentase \\
\hline \multirow{24}{*}{ Y } & \multirow[t]{5}{*}{1} & 1 & 0 & 0,0 \\
\hline & & 2 & 7 & 4,1 \\
\hline & & 3 & 53 & 31,2 \\
\hline & & 4 & 54 & 31,8 \\
\hline & & 5 & 56 & 32,9 \\
\hline & \multicolumn{2}{|c|}{ Total } & 170 & 100 \\
\hline & \multirow[t]{5}{*}{2} & 1 & 0 & 0,0 \\
\hline & & 2 & 0 & 0,0 \\
\hline & & 3 & 48 & 28,2 \\
\hline & & 4 & 75 & 44,1 \\
\hline & & 5 & 47 & 27,6 \\
\hline & \multicolumn{2}{|c|}{ Total } & 170 & 100 \\
\hline & \multirow[t]{5}{*}{3} & 1 & 0 & 0,0 \\
\hline & & 2 & 0 & 0,0 \\
\hline & & 3 & 28 & 16,5 \\
\hline & & 4 & 89 & 52,4 \\
\hline & & 5 & 53 & 31,2 \\
\hline & \multicolumn{2}{|c|}{ Total } & 170 & 100 \\
\hline & \multirow[t]{5}{*}{4} & 1 & 0 & 0,0 \\
\hline & & 2 & 14 & 8,2 \\
\hline & & 3 & 61 & 35,9 \\
\hline & & 4 & 54 & 31,8 \\
\hline & & 5 & 41 & 24,1 \\
\hline & \multicolumn{2}{|c|}{ Total } & 170 & 100 \\
\hline
\end{tabular}


Dari tabel 4.4 dapat diketahui bahwa responden yang menyatakan sangat tidak setuju tidak ada, yang menyatakan tidak setuju sebanyak 7 responnden $(4,1 \%)$, yang menyatakan cukup setuju berjumlah 53 responden $(31,2 \%)$, yang menyatakan setuju berjumlah 54 responden $(31,8 \%)$ dan responden yang menyatakan sangat setujuberjumlah 56 responden $(32,9 \%)$ dan seterusnya untuk soal no.2, no.3 dan no.4.

\subsection{Analisa Data Dan Pembahasan} a. Analisa regresi Linear Berganda
Untuk menguji hipotesis diatas diperlukan analisis $r_{22}$ linier berganda dengan mengg 221 SPSS 12.0 for windows. Tingkat kepercayaan yang digunakan dalam menghitung Regresi Linier Berganda adalah 95\% atau dengan tingkat kesalahan 5\% $(0,05)$.

Pada analisis Regresi Linier Berganda dilakukan uji f untuk uji secara simultan dan uji t untuk uji secara parsial. Secara ringkas hasil analisis regresi linier berganda terdapat dalam tabel berikut ini

Tabel 4.5

Rekapitulasi Analisis Regresi Linear Berganda

\begin{tabular}{|c|c|c|c|c|c|c|}
\hline Variabel & $\begin{array}{c}\mathrm{B} \text { (Koef. } \\
\text { Regresi) }\end{array}$ & BETA & $t_{\text {hitung }}$ & $t_{\text {tabel }}$ & Sig t & Ket \\
\hline Constanta & 1,601 & - & 7,867 & - & 0,000 & \\
\hline $\mathrm{X}_{1}$ & 0,515 & 0,649 & 10,712 & 1.800 & 0,000 & Signifikan \\
\hline $\mathrm{X}_{2}$ & 0,090 & 0,112 & 1,847 & 1,800 & 0,067 & Signifikan \\
\hline
\end{tabular}

Analisis ini member informasi seberapa baik model analisis kita secara keseluruhan, yaitu bagaimana 2 variabel bebas mampu mempengaruhi 1 variabel terikat atau dengan kata lain derajat keeratan hubungan antar variabel.

Tabel 4.6

Hasil Analisis Regresi Linear Berganda

\begin{tabular}{|c|c|c|c|c|}
\hline Model & $\mathrm{R}$ & $\begin{array}{c}\mathrm{R}- \\
\text { Square }\end{array}$ & Adjusted R-Square & Std. Error of the estimate \\
\hline 1 &, $703^{\mathrm{a}}$ &, 494 & .488 &, 28999 \\
\hline
\end{tabular}

Predictors: (constant), $\mathrm{X}_{2}$ (Bonus Pack), $\mathrm{X}_{1}$ (Price Discount)

Dari tabel diatas, dapat diketahui $\mathrm{R}=0,703$ yang berarti korelasi atau hubungan 2 variabel bebasnya adalah dalam taraf "Kuat".

a. Angka $\mathrm{R}$ Square atau Koefisien Determinasiadalah 0,494. Ini artinya bahwa 0,494 , variasi dari variabel $Y$ dapat dijelaskan oleh variasi dari kedua variable bebasnya.

b. Kolom adjusted $\mathrm{R}$ square. Fungsinya menjelaskan apakah sampel penelitian mampu mencari jawaban yang dibutuhkan dari populasinya. Kisaran nilai adjusted $\mathrm{R}$ square adalah 0 hingga 1 . Adjusted $R$ square adalah nilai $R$ square yang telah disesuaikan, nilai ini selalu lebih kecil dari $R$ square dan angka ini bisa memiliki harga negatif. Untuk regresi dengan lebih dari dua variabel bebas digunakan adjusted $R$ square sebagai koefisien determinasi. Dari tabel 4.6 dapat diketahui bahwa nilai Adjusted $\mathrm{R}$ square adalah sebesar 0,494 
c. Std. Error of the Estimate yang nilainya 0, 28999 menggambarkan tingkat ketepatan prediksi regresi, dimana semakin kecil angkanya maka semakin baik prediksinya.

222

\section{a. Pengujian Hipotesis}

Digunakan untuk menguji dan mengetahui tentang pengaruh Diskon dan iklan terhadap Minat Beli. Berdasarkan hasil penelitian SPSS ver 12 diperoleh hasil sebagai berikut:

\section{1) Ujif (Simultan)}

Tabel 4.7

Ujif (Simultan)

\begin{tabular}{|l|c|c|c|c|c|}
\hline Model & Sum of Squares & Df & Mean Square & $\mathrm{F}$ & Sig. \\
\hline 1. Regression & 13,693 & 2 & 6,847 & 81,413 &, $000^{\mathrm{b}}$ \\
Resiual & 14,044 & 167 &, 084 & & \\
Total & 27,737 & 169 & & & \\
\hline
\end{tabular}

a. Dependent Variabel: Y (Impulse Buying)

b. Predictors: (Constant), x2 (Bonus Pack), x1 (Price Discount)

Untuk hipotesis tersebut dilakukan dengan uji $\mathrm{F}$ yaitu pengujian secara simultan atau bersama-sama berpengaruh terhadap X1dan X2 secara simultan terhadapY. Besarnya $F_{\text {hitung }}$ 81.413 nilai ini lebih besar dari $F_{\text {tabel }}$
$(310,435>3,05)$. Dari hasil tersebut maka" Terdapat pengaruh terhadap variabel $X 1$ dan $X 2$ secara simultan berpengaruh terhadap variabel $Y$ " dan H-I (Hipotesis Satu) diterima.

\section{2) Uji t (Parsial)}

Tabel 4.8

Uji t (Parsial)

\begin{tabular}{|l|c|c|c|}
\hline \multicolumn{1}{|c|}{ Variabel } & T hitung & T tabel & Keterangan \\
\hline Price Discount $\left(\mathrm{X}_{1}\right)$ & 10,712 & 1.800 & Paling Dominan \\
\hline Bonus Pack $\left(\mathrm{X}_{2}\right)$ & 1,847 & 1,800 & \\
\hline
\end{tabular}

Berdasarkan tabel 4.8 dapat ditarik kesimpulan bahwa variabel $X_{1}$ dan $\mathrm{X}_{2}$ berpengaruh signifikan terhadap variabel $Y$. Sedangkan yang paling dominan mempengaruri variabel $Y$ adalah variabel $X_{1}$ (Price Discount) dan $\mathrm{H}$-II (Hipotesis dua) diterima.

\section{KESIMPULAN DAN SARAN}

5.1 Kesimpulan adalah

Kesimpulan dalam penelitian ini

1. item-item angket dari variable $\mathrm{X}-1$, $X-2$ dan $Y$ berdasarkan penghitungan menggunakan SPSS sudah valid dan reliable, kreana nilai $r_{\text {hitung }}>r_{\text {table }}$ mencapai diatas 0,30 dan Cronchbanch Alpha diatas $60 \%$ $(0,60)$.

2. Dari hasil analisa regresi linear berganda menggunakan SPSS dapat diketahui $R=0,703$ yang berarti korelasi atau hubungan 2 variabel bebasnya adalah dalam taraf "Kuat"

3. uji $F$ yaitu pengujian secara simultan atau bersama-sama berpengaruh terhadap X1dan X2 secara simultan terhadapY. Besarnya $F_{\text {hitung }}$ 81,413 nilai ini lebih besar dari $F_{\text {tabel }}$ $(81,413>3,05)$. Dari hasil tersebut maka" Terdapat pengaruh terhadap variabel $\mathrm{X} 1$ dan $\mathrm{X} 2$ secara simultan berpengaruh terhadap variabel $Y$ " 
4. Untuk setiap kontribusi dari variabel $\mathrm{X}_{1}$ akan mempengaruhi variabel $\mathrm{Y}$ sebesar 0,0515 dengan asumsi bahwa variable $X_{2}$ konstan. Dan setiap penambahan 1 riabel $X_{1}$ maka akan meningk: 223 ipulse Buying sebesar 5,15. Dan setiap kontribusi dari variabel $X_{2}$ akan mempengaruhi variabel $Y$ sebesar 0,090 dengan asumsi bahwa variable $\mathrm{X}_{2}$ konstan. Dan setiap penambahan 1 poin variabel $X_{2}$ maka akan meningkatkan Impulse Buying sebesar 0,090.

\subsection{Saran} adalah

Saran yang diberikan peneliti

1. Untuk Indomaret

Indomaret harus lebih meningkatkan Price Diskon karena lebih dominan dalam mempengaruhi Impulse Buying daripada Bonus Pack, namun bukan berarti harus mengabaikan Bonus Pack, karena Bonus Pack, juga mempengaruhi peningkatan Impulse Buying.

2. Untuk Peneliti Lanjutan

Dalam melakukan penelitian dengan judul yang sama, hasil penelitian ini mampu dijadikan pedoman dalam mengerjakan, namun lebih baik jika variable dan pengambilan objeknya lebih diperluas agar penelitian yang selanjutnya jauh lebih menarik dan jauh dari kesan plagiat.

\section{DAFTAR PUSTAKA}

Amanda Putri, Y.T. dan Edwar, M. 2014. Pengaruh Bonus Pack dan Price Discount Terhadap Impulse Buying pada Konsumen Giant Hypermarket Diponegoro Surabaya. Jurnal Manajemen. Universitas Negeri Surabaya.

Boyd, Harper W. 2000. Manajemen Pemasaran. Edisi Kedua. Erlangga. Jakarta

Engel, James F., R. D Blackwell., dan P. W Miniard. 1995. Perilaku
Konsumen. Binarupa Aksara. Jakarta

Ferdinand A . 2006. Structural Equation Modelling dalam Penelitan Manajemen. Edisi 2. 03/BPUNDIP. Seri Pustaka Kunci. Jakarta

Isnaini, A., 2005. Model dan Strategi Pemasaran. Erlangga. Jakarta.

Kotler, Philip, dan Armstrong, Gary. 2008. Prinsip- Prinsip Pemasaran. Edisi 12. Jilid 1 dan 2.Erlangga. Jakarta

Kotler, Philip \& Keller, Kevin. (2009). Manajemen Pemasaran. Edisi13 Jilid2. Erlangga. Jakarta.

Ma'ruf, H. 2006. Pemasaran Ritel. PT Gramedia Pustaka Utama. Jakarta.

Mowen, J.C. and Minor, M., 2002. Perilaku konsumen. Alih Bahasa Lina Salim, Edisi Kelima. Erlangga. Jakarta

Peter, J. Paul. dan Olson, Jerry. C. 2005. Consumer Behaviour and Marketing Strategy. Mc. Graw Hill. New York

Santoso, Singgih. 2002. Buku Latihan SPSS Statistik Parametrik. PT. Elex Media Komputindo. Jakarta.

Sugiyono. 2004.Metode Penelitian Bisnis. Alfabeta. Bandung.

Sugiyono. 2005. Metode Penelitian Kuantitatif Kualitatif dan $R \& B$. Alfabeta. Bandung.

Sutisna. 2002. Perilaku Konsumen dan Komunikasi Pemasaran. PT. Remaja Rosdakarya. Bandung

Tjiptono, F. 2008. Strategi Pemasaran. Andi Offset. Yogyakarta

Utami, C.W. 2010. Strategi dan Implementasi Ritel. Salemba Empat. Jakarta 